Olivia Afonso Magalhaes

BA, Carleton University, 2012

\author{
A Major Research Paper \\ presented to Ryerson University
}

in partial fulfillment of the requirements for the degree of

\author{
Master of Planning \\ in \\ Urban Development
}

Toronto, Ontario, Canada, 2018

(C) Olivia Afonso Magalhaes 2018 


\section{Author's Declaration for Electronic Submission of a MRP}

I hereby declare that I am the sole author of this MRP. This is a true copy of the MRP, including any required final revisions.

I authorize Ryerson University to lend this MRP to other institutions or individuals for the purpose of scholarly research.

I further authorize Ryerson University to reproduce this MRP by photocopying or by other means, in total or in part, at the request of other institutions or individuals for the purpose of scholarly research.

I understand that my MRP may be made electronically available to the public. 


\title{
SOCIOTOPE MAPPING: PERCEPTIONS OF PUBLIC SPACE AT RYERSON UNIVERSITY
}

(C) Olivia Afonso Magalhaes, 2018

\author{
Master of Planning \\ in \\ Urban Development \\ Ryerson University
}

\begin{abstract}
Sociotope mapping is a tool that has been used to identify values in public spaces, as defined by the public. By developing an original sociotope map using the sociotope map methodology, utilizing the technique created in Stockhom, Sweden, this research attempts to understand the values of public space within and around Ryerson University, while providing a critique on the utility of the tool in this context. The information collected from an online survey will be analyzed and visually displayed on a sociotope map. This may be utilized by the school administration, municipal planners, urban designers or landscape architecture professionals to understand what concerns may be provoked by the development of certain spaces and the resources valued by the public in the public realm. This project explores how different public spaces within the Ryerson University Campus are utilized and how useful is the sociotope mapping tool in inferring these values.
\end{abstract}

keywords: planning; sociotope; parks planning; perceptions of space; engagement; public consultation. 


\section{Acknowledgements}

First of all, I would like to thank my family for their consistent support and encouragement throughout these rewarding but difficult two years. To my parents, thank you for all that you have sacrificed to get me here and giving me the freedom to grow into my own. Sandra and Christine, thank you for always being such great role models for your, not so little, little sister. I love you all very much.

I would like to thank my supervisor, Dr. Chris De Sousa, for all his support through this process and his voice of reason. Thank you to my second reader, Jennifer Kowalski, for taking the time to give me insightful feedback.

I would like to thank my classmates, who have taught me so much about planning and myself. Amanda and Steve, thanks for always making me laugh until I cry and lifting me up.

Finally, thank you to my friends for always being there. I could not have done it without your support and love. Thank you to Pleurat, I am very grateful for your patience and willingness to help. 


\section{Dedication}

I want to dedicate this research paper to my two nephews, Nolan and Xavier. May you both follow your hearts and passions to excel on your respective paths. 


\section{Table of Contents}

Author's Declaration for Electronic Submission of a MRP ii

ABSTRACT iii

Acknowledgements

Dedication $v$

Table of Figures viii

List of Appendices $\quad$ ix

\section{Part 1}

Introduction $\quad 1$

The Sociotope Map 3

Literature Review $\quad 6$

Values in Public Space $\quad 6$

Who Belongs $\quad 8$

$\begin{array}{lr}\text { Assessment of Urban Space } & 9\end{array}$

Municipal Public Space Assessment 13

$\begin{array}{ll}\text { West Vancouver } & 13\end{array}$

$\begin{array}{ll}\text { Edmonton } & 14\end{array}$

$\begin{array}{ll}\text { Toronto } & 15\end{array}$

The Role of the Sociotope in Improving Parks Planning 16

$\begin{array}{ll}\text { Practitioners Versus Users } & 18\end{array}$

\section{Part 2}

Methods $\quad 21$

Site Location $\quad 21$

Literature Review $\quad 22$

$\begin{array}{ll}\text { Survey } & 22\end{array}$

Expert Analysis $\quad 23$

Survey Application $\quad 23$

$\begin{array}{ll}\text { Sociotope Mapping } & 24\end{array}$

$\begin{array}{ll}\text { Limitations } & 24\end{array}$

$\begin{array}{ll}\text { Results } & 26\end{array}$ 
Value of Public Space $\quad 28$

$\begin{array}{ll}\text { The Kerr Hall Quad } & 28\end{array}$

$\begin{array}{lr}\text { Gould Street } & 29\end{array}$

Devonian Pond $\quad 29$

Overall Results $\quad 29$

$\begin{array}{ll}\text { Duration of Stay } & 29\end{array}$

The Kerr Hall Quad. $\quad 30$

$\begin{array}{ll}\text { Gould Street } & 30\end{array}$

$\begin{array}{ll}\text { Devonian Pond } & 31\end{array}$

Overall Duration 32

Frequency of Use 33

The Kerr Hall Quad 33

$\begin{array}{ll}\text { Gould Street } & 34\end{array}$

$\begin{array}{ll}\text { Devonian Pond } & 34\end{array}$

Overall Frequency $\quad 35$

Attraction to Space $\quad 36$

$\begin{array}{ll}\text { The Sociotope Map } & 37\end{array}$

$\begin{array}{ll}\text { Discussion } & 40\end{array}$

Sociotope Application $\quad 40$

Tool Utility $\quad 42$

$\begin{array}{ll}\text { Conclusion } & 46\end{array}$

$\begin{array}{ll}\text { Bibliography } & 50\end{array}$ 


\section{Table of Figures}

Figure 1: The Sociotope Map $\quad 4$

Figure 2: Local Parkland Provision - Map 8B 21

Figure 3: Map of Ryerson University favourite places on campus 26

Figure 4: Favourite Spaces at and around Ryerson $\quad 27$

Figure 5: The Quad Duration of Stay in Winter and Fall 30

Figure 6: The Quad Duration of Stay in Summer and Spring 30

Figure 7: Gould Street Duration of Stay in Winter and Fall 31

Figure 8: Gould Street Duration of Stay in Summer and Spring 31

Figure 9: Devonian Pond Duration of Stay in Winter and Fall 32

Figure 10: Devonian Pond Duration of Stay in Summer and Spring 32

Figure 11: Overall Duration of Stay in Winter and Fall 32

Figure 12: Overall Duration of Stay in Summer and Spring. 32

Figure 13: Frequency of Use in Winter and Fall 33

Figure 14: Frequency of Use in Summer and Spring 33

Figure 15: Frequency of Use in Winter and Fall 34

Figure 16: Frequency of Use in Summer and Spring

Figure 17: Devonian Pond Frequency of Use in Winter and Fall 35

Figure 18: Devonian Pond Frequency of Use in Summer and Spring 35

Figure 19: Frequency of Use in Winter and Fall

Figure 20: Frequency of Use in Summer and Spring 35

Figure 21: Overall Reason For Liking a Space 36

Figure 22: Perceptions Quantity of Parks 36

Figure 23: The Sociotope Map of Public Space In and Around Ryerson University Campus 37 


\section{List of Appendices}

Appendix A 


\section{Part 1}

\section{Introduction}

In the realm of urban planning, a recent paradigm shift has produced a departure from the antiquated concept of rational planning to a collaborative process incorporating and valuing public opinions. As planners and processes shift, there is a need for innovative and unique approaches to collecting information in a manner which facilitates conversations and comprehends citizens' perceptions. In the municipality of Stockholm, Sweden, the sociotope map emerged in light of the aforementioned situation and as a tool to engage citizens in a larger dialogue surrounding the perceptions and use of public open space. This tool is a method which has been used in other municipalities within the Scandinavian context, however, this is the first application of this method in North America.

In the context of downtown Toronto, citizens are living in higher densities, in vertical communities that have little to no access to green space (Lorinc, 2015). As development pressure increases in these already tight spaces, there will be pressure on the green spaces that currently exist. However, not all public spaces are created or utilized equally, and users' perceptions may differ about these spaces. This raises the question of how do planners quantify and understand the community's perceptions and values of these public spaces.

This project aims to apply the method of sociotope mapping on a small scale, at Ryerson University campus in downtown Toronto, Ontario. The key outcomes of this project will be to 1 . Assess the urban spaces around the Ryerson University campus 
and the associated values related to them; 2 . Understand the sociotope tool and its application in the Canadian context; 3 . Evaluate its success while providing recommendations for future application. This project wishes to answer how different public spaces within the Ryerson University Campus are utilized and how useful is the sociotope mapping tool in parks planning?

The contents of the paper have been separated into two distinct parts. Part 1 will provide the context and inform the reader of the history of the sociotope method. Next, it will explore relevant research addressing values and perceptions of public space, theories of measuring public space, and current methods of evaluation utilized by three Canadian municipalities. Part 2 will outline the methods to undertake the research, and the results of the sociotope mapping exercise at Ryerson University. It will discuss the relevance of the tool, its potential role in parks planning in the Canadian context and recommendations for future use and research. 


\section{The Sociotope Map}

To understand how the sociotope will be utilized in the context of Ryerson University, one must first acknowledge the context of this tool. The sociotope map emerged in Stockholm as the importance of perceptions and values of public space came to the forefront of planning dialogue in Sweden during the mid-1990s. Historically, as the City of Stockholm developed, it grew radially along commuter train routes. Development occurred in clusters along the train lines with the outlaying fringe left to remain as forested areas, utilized as recreational and green space for residents. These areas between the communities have become defined by the local government as the "Green Wedges" and are utilized as spaces for recreation, relaxation and access to nature for residents and visitors alike (Cardiff University, n.d). As population increases and development pressure threatens these green spaces, the City of Stockholm responded through the development of the Green Map as a method to evaluate the values and uses of public space. Additionally, this tool has created a platform for dialogue about public space before the threat of development is imminent.

The Green Map is a comprehensive planning tool that includes three separate but interrelated maps. The information layered in the Green Map is shown through the sociotope map, the biotope map and the recycling map (Stockholm Stad, 2017). The biotope is one that identifies biodiversity of flora and fauna utilizing landscape ecology (COST, 2012). The recycling map identifies the functions of, "recycling of nutrients, wastewater treatment, energy production, and areas functioning as "shelterbelts" improving urban climate" in various locations (Kettunen et al., 2012). The sociotope map 
addresses the social and the cultural dimensions of public space, and the perceptions of these spaces by citizens in municipalities.

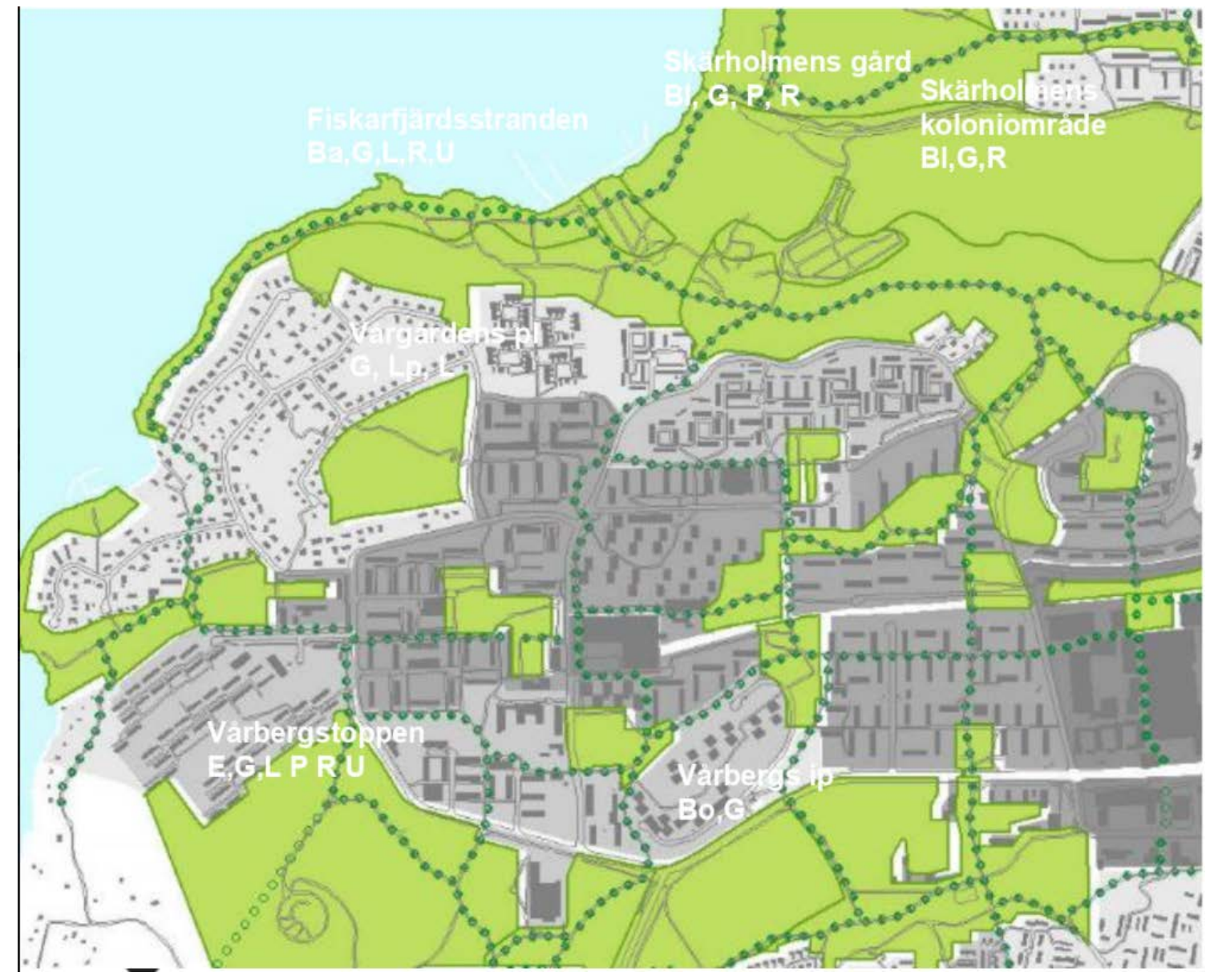

Figure 1: The Sociotope Map (Stockholm Stad, 2017).

Anders Sandberg and Alexander Stahle, while working for the Strategic Planning Department at the City of Stockholm, needed a way to address social values in the landscape. They created the sociotope map and the municipal government produced their first version of it in 2000. Since this time they have utilized it as a method to engage in dialogue with the public to assess the value of different public spaces. This process has led to opening up coversations about valuable green space before 
development occurs and an understanding of how development in these places may spark a reaction in the public. Through this process, the public was engaged and surveyed regarding their perceptions of space through means of focus groups, newspaper surveys, web-based surveys, and surveys mailed to their homes (Ståhle, Sandberg, \& Nordström, 2003). Citizens in different age groups with different abilities were engaged to understand how users from various demographic groups perceive and value public space.

In addition to asking the public their opinions, experts in fields related to parks and public realm, such as landscape architects and natural historians, evaluated the public spaces. The information they collect was synthesized with public opinion and the public spaces are categorized by twenty different direct use values (Ståhle, n.d). The direct use values that have been identified by the Municipality of Stockholm in the Sociotope Manual are: green havens, games, calm or relaxation, sunbathing, walking, flowers, community life, picnic, ball games, swimming, agriculture, events, fishing, toboggan, ice-skating, forest, history, viewing point, water activities and wildlife (Ståhle, Sandberg, \& Nordström, 2003).

Now that sociotope mapping has been understood, where it fits with the wealth of existing knowledge on parks perceptions and measurement will be explored. 


\section{Literature Review}

When creating a sociotope map, the process of doing so considers the perspectives of multiple users of space. In order to better understand these experiences, a scan of literature related to perspectives of public space was conducted. Additional literature was sourced to inform the research regarding other methods of measuring park space that are currently employed. The following is a synthesis of relevant and available research on these topics.

Values in Public Space

The sociotope is a map which interprets information to convey social meaning and values embedded in the physical landscape. As there are a variety of conditions which influence citizens use of public spaces more frequently, what factors have other studies demonstrated that influence use in these spaces? The way in which people feel about a space will influence their evaluation of it and may have positive influences on the frequency of use, and the value of this space.

Public spaces are important places for recreation, socialization and relaxation. The elements included in parks can influence what user groups access the space (McCormack, Rock, Toohey, \& Hignell, 2010). With demographics in mind, play and sports are crucial for attracting younger populations, trails are an important aspect of parks for adults and dog owners feel that trash bins are a necessary component of urban spaces (McCormack et al., 2010).

Although physical features of a park may influence use, the upkeep of these features is equally important, such as the appearance of grass or the presence of litter. 
Water and plants are associated with increased park use, whereas the presence of vandalism tends to discourage park use (McCormack et al., 2010). The feeling of safety and perceived distance to travel to access green space also have the effect of determining use (Lee et al., 2017).

As Toronto has become denser, the cost of living space has increased creating the need for recreational activities to occur in the public sphere (Allen, Amano, Byrne, \& Gregory, 2009). It has been found that those of varying socioeconomic status conceptualize the use of park space differently, which may relate to the lack of space in housing. Those from middle-class residential areas value space due to its environmental utility, however, those of lower socioeconomic status value them for their socialization utility (Lo, 2010. Lee, Gu, \& An, 2017) Socialization can be encouraged through the programming of a space such as facilitating festivals, markets or community activities to clean or upkeep a park (McCormack et al., 2010). This will engage residents in social activities at the open spaces thereby improving park use, which may lead to positive perceptions of the spaces.

The research points to certain aspects which make an urban public space more desirable, however, it should be noted that context matters. Those inhabiting a warmer climate might cite the presence of shade as a positive, although those in a local with less exposure to sun may desire less shade (Nasution \& Zahrah, 2014). Additionally, perceptions of green space are dependent on the type of environment which the interviewees live in. Often times, those inhabiting a suburban area do not value green space as much as their urban counterparts (Arnberger \& Eder, 2012). Although the users of Ryerson's open space who completed the survey were not asked where their 
place of residence was, the mere fact that Ryerson is in an urban context could have users valuing the space more.

Who Belongs

Ryerson University is in the heart of downtown Toronto. It is nestled among apartment buildings, office towers and steps from a major tourist attraction, therefore, may attract users of the public not affiliated with Ryerson University to utilize the open space. As Ryerson University is patrolled and regulated by security, it brings to light who belongs and who does not in these spaces.

Facilities and accessibility such as parking, washrooms or street vendors have the potential to improve perceptions of the space (Nasution et al., 2014). Accessibility is seen as who may access it, how difficult it is to reach the space and explores other issues of who the space is for (Németh, 2012) These two components both bring to light the blur that exists on Ryerson University's campus between the private that the public. A member of the Ryerson community may feel that Ryerson's public spaces are accessible with good facilities, however, this might not be felt from one unfamiliar with Ryerson. Also, this perception may differ depending on their mode of travel or whether one has a physical disability. This may change values found on the map depending on who completes it.

Perceptions of safety in public space can also influence how the public values space. Perceived danger of a space may differ depending on the time of day it is used, the identified gender of those utilizing the space, the presence of who they feel is a threatening community member, car traffic or even fast moving cyclists on paths 
(Blöbaum \& Hunecke, 2005., McCormack et al., 2010). Additionally, spaces that are unkempt and unlit have been associated with gangs and places where predators can hide (Lo, 2010). The way public space is designed may alleviate some of these perceptions such as lighting, exits allowing for those using the space to escape in the case of danger and reducing physical elements where an attacker might be able to hide (Blöbaum, 2005).

The perceived danger of others that are thought to be threatening brings to the surface questions about who does and does not belong in these public spaces. Is a space public truly public if people are excluded from the place, such as homeless or drug users? Often times, these members of the community are removed from the perceived public space, at Ryerson University (Sloan, 2016). This can have the effect of improving the perceived level of safety on Ryerson University's campus, but at what cost? However, one may be deterred to utilized public space if their personal safety feels at risk (McCormack et al., 2010). With this in mind, does inclusive and safe public space exist in unison, as perceptions of space differ among the users?

Understanding what values of public space research has uncovered in regard to public space helps in assessing the utility of the sociotope map and brings to light what gaps are present in this method. The following will discuss methods used by planners to assess public space.

Assessment of Urban Space

Through the urban landscape, park spaces act as an oasis for escape, a recreational haven, a living space for socialization, or a shortcut away from street traffic 
(Jurkovič, 2014). In the assessment of public spaces, how may the qualities of urban space be measured and the values of space be expressed?

Public spaces in the city should be dynamic where people can relax, sunbathe or people watch and where life occurs and moves through fluidly. However, public spaces can be difficult entities to measure as the number of public spaces does not always equate to quality. There must be a deeper analysis that reflects on the successes and failures of these spaces. Various scholars and practitioners within the discipline of Urban Planning have developed specific methods in the pursuit of understanding the use of public space within our cities. The most notable surveyors of public life in these spaces are William H. Whyte, Kevin A. Lynch and Jan Gehl. The infamous urbanist Jane Jacobs can also be seen as an advocate for high-quality public spaces, and through her work often describes the benefits of them, however, her lack of measurement and assessment tools was the rationale for not including her ideas in this section (Cooke, 2015). The following is a brief overview of the theorists and the methods they have utilized when assessing public space.

William $\mathrm{H}$. Whyte was an innovator in the school of thinking surrounding public spaces and how the public utilizes and behaves within them. In 1969, he was involved with the planning of New York City and was interested in discovering the success of planned spaces (Project for Public Spaces, 2010). This was an interesting time as pedestrian life was declining due to the prevalence of the automobile. In 1970, Whyte began The Street Life Project whereby his research group utilized time-lapse photos to observe the behaviour of users of public space, specifically in Manhattan, as a means to unmask the idea that density was negative and equated to unlivable conditions 
(Fitzpatrick, 2016. Whyte, 2001). By systematically observing the public use of space, Whyte produced a set of guidelines that are still utilized to this day. These relate to the presence of food, the form of seating, the elements integrated into a space and the use of microclimates to make public space more comfortable. In The Social Life of Small Urban Spaces, he outlines that, in addition to the aforementioned time-lapse cameras, the researchers spoke with users of the space to find out their demographics, how often they used the space, and their perceptions of it (Whyte, 2001). Although the Whyte method could be beneficial for informing planning interventions, it requires a great deal of time to conduct individual interviews and analyze each photo taken over the time period.

Kevin A. Lynch is an American Planner who is well known for his urban theories about perceptions of space (Caves, 2005). Through his research regarding perception, he arrived at the concept that there are five main elements utilized in reading a city: paths, nodes, edges, districts and landmarks (Lynch, 1960). He utilized the method of conducting citizen interviews and mapping exercises to reach this understanding. According to Lynch, these elements are part of the legibility of a city and how users understand the spaces through the conveyance of their mental images of the city. Utilizing this method, perceptions of space are explored, however, feelings of specific spaces are not uncovered (Lynch, 1960).

Jan Gehl is a Danish urbanist who concluded his training in architecture in 1960. Since that time, he has contributed and influenced the thinking of planners a great deal in the realm of public spaces and how the design of cities should be primarily focused on people (Gehl, 2010). The core of his work has been around challenging planning that 
puts vehicles first and taking back space on the street for life to occur at a slower pace. Through this, he has designed methods to extract data from public spaces to inform planning processes, as seen through his work with the City of Toronto's TOCore study (Gehl People, 2016).

In Gehl and Svarre's (2013) book, How to Study Public Life, they outline a variety of different methods to be utilized when assessing public spaces and their use. Moving past basic methods such as how many people are in the space, it discusses metrics surrounding questions of who is present in the spaces, what activities are they engaged in, the time they spend there, where they move through the space, the pace in which pedestrians move through a space and how much lingering occurs in spaces, among others (Gehl \& Svarre, 2013). The literature dives deeper to illustrate various tools that can be employed in order to organize and keep track of this data. They suggest that the best tools for this are: counting, mapping, tracing, tracking, looking for traces, photographing, keeping a diary and test walks. Gehl has produced other books and toolkits to measure unique qualities of public space, most notably his recent work in understanding the diversity of public life (Gehl Institute, 2016).

These tools are useful for quantifying use and movement through a public space, however, they fail to acknowledge the personal perceptions one holds of public spaces. The sociotope tool asks the user the space that they prefer and from there, dives deeper to understand the frequency of use, duration of stay and the rationale behind these points. The sociotope attempts to put a social lens to truly understand the human motives around use and perceptions of public space. 
Municipal Public Space Assessment

The following is a brief overview of the methods that Toronto, West Vancouver and Edmonton have employed when assessing public spaces and producing their plans for parks in the past. These include a range of quantitative and qualitative research methods.

West Vancouver

In the West Vancouver Parks Master Plan, a range of approaches were employed when producing their parks plan (West Vancouver, 2012). These take shape through public consultations, best practice and quantitative research.

For the creation of this plan, West Vancouver ran public consultations with many different groups and stakeholders. They created the Parks Master Plan Working Group that had biweekly meetings from July to September. They had a Stewardship Input Forum where twelve groups were asked to write a short submission about the work they were involved in and their input on the plan. They ran workshops and pop-ups around West Vancouver as well as specific meetings with groups such as people living with disabilities, youth and district staff. Finally, they orchestrated two Public Open Houses where members of the public were able to voice their opinions (West Vancouver, 2012).

Further research was conducted by means of a scan of best practices from other municipalities as well as its own. The areas of dog ownership and services, urban agriculture, recreation activities and facilities, transportation and accessibility as well as parkland supply were explored. Parkland supply measurement was employed through a 
population-based parkland supply calculation which uncovered how many hectares of parkland existed per 1000 people (West Vancouver, 2012).

Additionally, quantitative data was collected to understand the needs of the population as a whole. In order to accomplish this, demographic data was analyzed exploring population growth, aging populations and low-income populations (West Vancouver, 2012).

Edmonton

The City of Edmonton recently released the Breathe Network, a plan produced to guide the future of parks planning in the municipality. For the assessment of parks, Edmonton looked at a geospatial database, sociodemographic data, public consultation, best practice research and a review of existing policies (City of Edmonton, 2017).

The geospatial database of open space contained a vast array of information about connectivity and use. This database allowed for an analysis and measurement of the distribution, quality (value, infrastructure and amenity quality), diversity (different types of park space) and supply of parks. Data was collected regarding sociodemographics of Edmonton to not only understand the current composition of population but also to predict future trends in population (City of Edmonton, 2017).

In order to engage park users, public consultations were conducted employing a variety of methods. This was completed through questionnaires and mapping which residents could access online. Over forty-five events were held, including open houses, stakeholder meeting and workshops as well as pop-up engagements. Additionally, they facilitated meetings with community groups, indigenous communities and sensitive 
groups such as children, youth, disabled, older adults, and newcomers (City of Edmonton, 2017).

Best practice research was conducted to provide a comprehensive understanding of how other jurisdictions address similar problems in addition to successful practices occurring within Edmonton's jurisdiction. Finally, policy was reviewed from all levels of government to understand how these directions may guide the plan (City of Edmonton, 2017).

\section{Toronto}

Currently, the City of Toronto is undergoing the Phase 2 of their Parkland Strategy which is a plan that will support planning throughout a twenty-year timeframe. During Phase 1 of the Strategy, the City employed a variety of methods and approaches to understand the parkland needs (City of Toronto, 2017b). The City of Toronto utilized mapping to assess parkland accessibility and supply, consulted with internal and external stakeholders and reviewed policy pertaining to parkland.

To determine the amount of parkland in hectares per 1,000 people, the City has traditionally utilized a tool called Local Parkland Assessment Cells. A cell is defined as an area bounded by physical barriers that make it difficult to access a park. However, this report puts forth the recommendation to modify the tools used to assess parkland within Toronto (City of Toronto, 2017b). It proposes to utilize the boundaries of the smallest census dissemination unit, instead of a cell, as it is finer grain and can be compared directly to census data, such as dwelling units and population. The report continues to recommend updating measures to quantify the walkability to parks, known 
as the Catchment Areas, as well as to alter the classification of parks taking into account size, not use (City of Toronto, 2017b).

Another method to measure parks was to engage the public over a five-month period, from May until October 2017. This helped collect feedback and provide useful information to produce the Phase 1 report. Four distinct groups were consulted and are described as external stakeholders, internal stakeholders, advisory boards, and councils as well as citizens around the City. The external and internal stakeholders were engaged in workshops with members of the City and were composed of groups of representatives from the public and private sector as well as non-profit organizations (City of Toronto, 2017b). Engagement with the public was completed by means of an online survey, twenty-one pop-up events and four open houses. They engaged with advisory groups such as the Toronto Planning Review Panel and the Aboriginal Affairs Committee.

Finally, policies were reviewed at all levels of Government along with other strategies that the City that may influence this document.

Currently, these municipalities are undergoing lengthy engagement strategies but still do not fully encapsulate the public perception on a large scale. The sociotope could be a tool utilized to fill that gap.

The Role of the Sociotope in Improving Parks Planning

As mentioned earlier, currently in the realm of planning there is an emphasis on consultation of the public and working with these actors to create better open urban spaces (Jurkovic, 2014). When considering the creation of a new open space, or the 
redesign of an existing space, it is especially crucial to have users involved in the early stages of planning. This will allow those involved in the project to understand the various social and psychological dimensions of the space and how the users may perceive and use it. This is why a sociotope is such a useful tool.

With the urbanization of city centres, there is a competition amongst uses for space in these urban areas. One of these aforementioned uses that is desired by residents are green open spaces. Green spaces in the urban environment have been found to rank higher on visual aesthetic when they are clearly demarcated areas with specific identity traits (Perovic \& Folic, 2012). Understanding the perceptions that user's hold in regard to public open spaces, such as the former statement, is of value to study as it informs the elements to create new public spaces. By opening up a dialogue process with users in regard to their perceptions of space it may have the effect of enticing them to be more involved with the planning process.

While exploring perceptions of space literature, the notion of attachment to urban green spaces is raised (Arnberger et al., 2012). As the sociotope is a dialogue process, citizens attachment to the places which they enjoy visiting is demonstrated. This attachment is important when considering where development is going to occur in the urban environment and which ways to mitigate neighbourhood approval or backlash against specific developments.

Those with increased social and political involvement will be more attached to a site (Arnberger et al., 2012). Therefore they are more likely to voice their values about this space, such as completing the sociotope survey. It can be assumed that if one is 
engaged politically, they may be more aware of developments occurring in their neighbourhoods and be vocal in their opinions. The sociotope could be a starting point for creating discussion and a relationship building mechanism among these groups. By keeping residents engaged and informed, it may benefit the development process.

In other studies measuring perceptions of public space, researchers put forth questions to focus groups about open spaces in their area that made them feel both comfortable and uncomfortable (Jurkovic, 2014). This method identifies the positive and negative experiences of the public in urban public spaces. This is divergent from the sociotope method, which only asks participants about their most valued open space. This demonstrates how the dialogue is shaped from those in power through which questions are asked and which are failed to be asked (Jurkovic, 2014). The tool of the sociotope is evidently one that is employed to discover which areas are most valued areas so they or their characteristics may be protected in the case development begins to encroach on them. However, it should not be utilized as an assessment tool to understand the open spaces that need improvement, unless altered to include this aspect.

Practitioners Versus Users

Urban public spaces can be used for a myriad of purposes. There are instances when these spaces are utilized as one's backyard, a place to socialize or relax. However, within the urban context, these spaces can also be a place of economic activity. The perspectives of public space from the standpoint of the public and professionals are explored in a British study in relation to the themes of design, 
economics, and culture (Pugalis, 2009). The idea of people watching or a space being animated can improve the quality of a space, making the mundane tasks that one has to perform seem more entertaining. Jane Jacobs also describes this road theatre that exists and the temporal component of public spaces, when speaking of the streets of Greenwich Village (Jacobs, 1961).

The author discusses the significance of urban design and the amount of thought put into designing Newcastle's Monument in London. The users of the space do not seem to value the design or architectural elements, however they recognize the utility of public space for social interactions (Pugalis, 2009). There are divergent views and values in regard to what components are the most crucial in creating a high-quality public space depending if the opinion is from the perspective of the public or a professional. From the public's perspective, the use of markets in public spaces is what brings people there and makes the space animated. However, the professionals prioritize the architecture and materials used to build the space and merit these components for the success of the space. In this study it suggests a concern from professionals about safety and a want to declutter streets to make them single purpose and inflexible, whereas the public view this as taking away the unique organically occurring public expressions. This presents an interesting point which relates to the sociotope, as the public spaces are identified and their utility is presented from the public's perspective, however, a professional will visit these spaces and assess them. These two views and perspectives are then synthesized to create the sociotope. This method may be nuanced because the body which creates the sociotope inevitably has 
the power to determine which knowledge should be valued greater when creating the map.

Understanding the breadth of research that has been conducted relating to public urban spaces sheds light on the use of the sociotope tool. This tool, although utilized in many Nordic countries has never been employed in a North American context. This is a unique opportunity to utilize this tool to understand perspectives of open green space in a distinctly urban campus. 


\section{Part 2}

Methods

Site Location

Ryerson University is in the downtown area of Toronto, the largest city in Canada. Ryerson offers programs to students at both the undergraduate and graduate level with over thirty thousand enrolled students (Ryerson University, 2018). The highest concentration of campus buildings are situated in an area bound by Yonge Street on the west, Gerrard Street East on the north, Jarvis Street on the east and Dundas Street East on the south. It sits in an area of the city that has a population density of 23,044 people per square kilometre, according to the 2016 census (City of Toronto, 2017a). The site is about 18 hectares and has a range of different public open spaces that serve different functions, including a grassy quad, a pedestrian street and a pond that doubles as a skating rink during the winter.

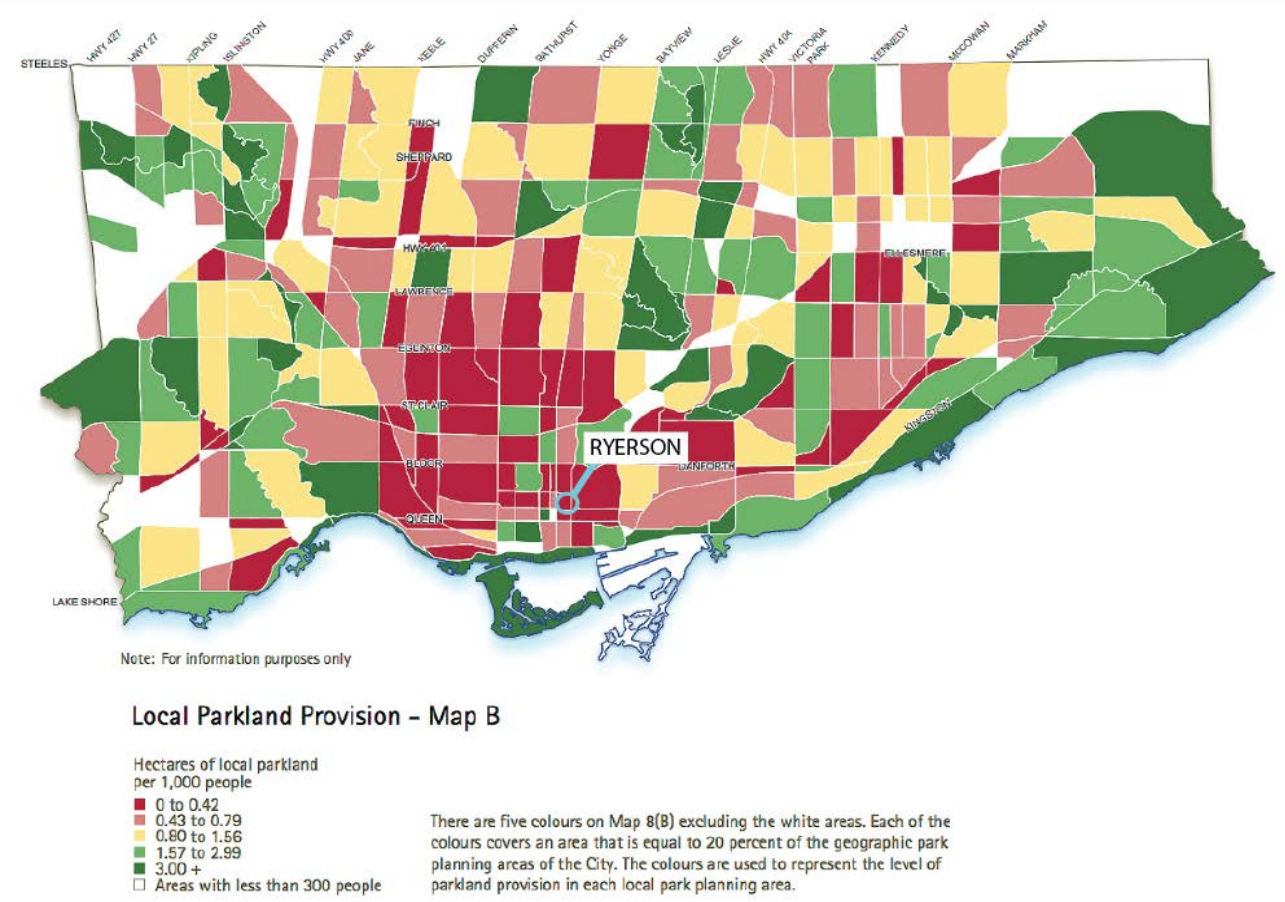

Figure 2: Local Parkland Provision - Map 8B demonstrates the amount of park space in hectares to 1000 people. (Toronto, 2006). 


\section{Literature Review}

In order to understand the use of the tool, its utility and its role in the larger academic field of study, a literature review was conducted. A thorough scan of literature was undertaken in order to understand the methods and application of the sociotope map as well as how to produce it. Additional literature exploring the perceptions of users of parks and urban open space was found and analyzed. This literature was useful in shaping the comprehension of how different users value green open space in other contexts and how this may differ in the context of Ryerson University. The literature surrounding the means in which other municipalities, planners, and theorists have employed public space evaluation was explored. Research regarding these methods to evaluate park space was sought out as this aided in the understanding of the strengths and weaknesses of this tool in comparison to others which have been utilized in the past.

Survey

To gain the information regarding perceptions of the open spaces at Ryerson, it was necessary to create a forum in which dialogue was encouraged with users of these spaces about their experiences. To gain this knowledge, a survey was created on Google Forms and then disseminated to the public. This online survey asked various questions about the user's favourite space on or around campus and follow up questions which explored the frequency and duration of their stay in these spaces (Appendix A). This aided to understand their use as well as their perceptions of the space. The questionnaire was created based on a survey which the Municipality of 
Stockholm had previously utilized to help inform the production of a sociotope map and that was translated into English (Stahle, 2003). The survey was sent to both students and members of the Ryerson Community through a posting on Facebook. Additional recruitment was conducted by sending out the survey to students of the Faculty of Community Services School of Urban and Regional Planning.

Expert Analysis

The next component of the sociotope method is to have an expert analyze the sites that had been identified that fit within the definition of public space. The expert is to visit the public spaces and assess them based on a set of qualities.

Survey Application

The data from the online survey was collected and then organized based on the location that the respondents had reported as their favourite open space around Ryerson University's campus. From there, the qualities and values of each space were ranked to understand the rationale behind why the users valued them. To understand the temporal nature of these sites, use was evaluated based on how long users spent in this space and on the frequency of use. These questions were asked for the summer and spring, as well as fall and winter. The three most commonly chosen public spaces were identified and discussed regarding the frequency of use as well as the general duration of stay. 


\section{Sociotope Mapping}

The final step in the methodology was to create the sociotope map to describe the values and perceptions that the public sees in the various public spaces. In the end, the views of the public were used to produce a holistic perception of the public space. The responses from the survey participants were analyzed and placed into the various direct use categories defined by this project and related to those defined by the Municipality of Stockholm's Sociotope Handbook (Ståhle, 2003). Due to the unavailability of a clear method in English, it was difficult to utilize the direct use values which the Municipalities Handbook make reference to. The researcher categorized the various values into the categories of social, views (people and things), relax/peaceful, food, winter activity, clean, nature, safety and sunbathe. As some localities on campus were only noted by one respondent as their favourite space some of the values had to be overridden to create a clear map. In this case, the initial proximity indicator was removed from the list of values and peacefulness and relaxation were amalgamated to create one value. Using GIS, a map was produced and labelled to indicate the location of the valued public spaces and their corresponding values.

\section{Limitations}

When the Municipality of Stockholm created the sociotope map, they did so by means of the aforementioned survey but also included focus groups with citizens of different abilities and ages. Due to the scope of this research as well as time and 
capital constraints, this method was not employed for the creation of Ryerson's sociotope map.

In regard to the expert analysis component, the expert would be expected to visit the space for ten minutes at a time in two different seasons, therefore, understanding its use and utility to residents in different weather conditions (Ståhle, 2013). An additional limitation of this approach is that the professional may have a bias regarding what information should and should not be included, which is difficult to avoid. Due to time, money and available information regarding the method to conduct the expert analysis, it was not possible to expand the scope of the project to include this portion.

A further limitation of the study was that it did not take into consideration accessibility of space, and how one not affiliated with the Ryerson community would interpret the spaces on campus. Additionally, the study did not collect information regarding mode of travel or whether the person lives with a physical disability, which may alter their valuation of the spaces. However, this study seeks to identify values within the landscape at a superficial level and does not intend to comprehend why the user values space in this manner. 


\section{Results}

From the dissemination of the survey, the study was able to secure one hundred responses. Through the review of the data collected, fifteen responses did not fit within the boundaries of the research and were omitted. Of these respondents, $65 \%$ of them identified as female, $34 \%$ identified as male and $1 \%$ identified as other. The average age of those who responded was 22 years old and the median age was 21 years old. Citizens' responses from the survey as well as the independent analysis of the sites are outlined below

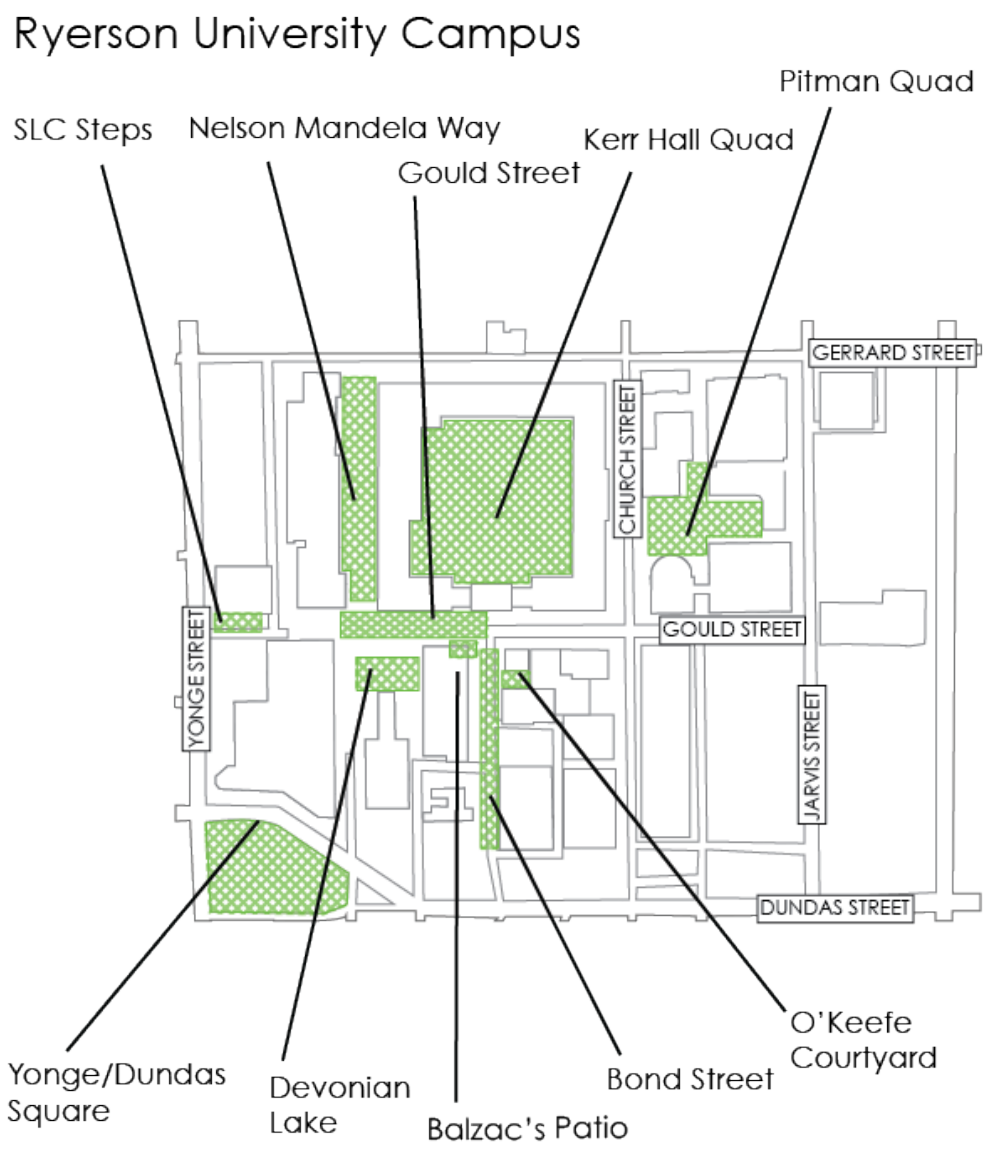

$\hat{T}_{\mathrm{N}}$

Figure 3: Map of Ryerson University favourite places on campus. 
From the eighty-five responses that were collected from the public, respondents identified ten different public spaces, both on and around campus. These ten favourite spaces are Balzac's Patio, Bond Street, Devonian Pond, Gould Street, the O'Keefe Courtyard, Pitman Quad, Yonge-Dundas Square, the Student Learning Centre (SLC), the Kerr Hall Quad, and Nelson Mandela Way. The following figure (Figure 4) shows this data through the use of a table.

\begin{tabular}{|l|l|}
\hline Favourite Space & $\begin{array}{l}\text { Number of } \\
\text { Responses }\end{array}$ \\
\hline The Kerr Hall Quad & 44 \\
\hline Gould Street & 13 \\
\hline Devonian Pond & 9 \\
\hline Balzac's Patio & 6 \\
\hline $\begin{array}{l}\text { The Student Learning Centre } \\
\text { Steps }\end{array}$ & 5 \\
\hline Pitman Quad & 3 \\
\hline Yonge-Dundas Square & 2 \\
\hline Bond Street & 1 \\
\hline O'Keefe House Courtyard & 1 \\
\hline Nelson Mandela Way & 1 \\
\hline & 85 \\
\hline
\end{tabular}

Figure 4: Favourite Spaces at and around Ryerson

Out these responses, 44 respondents chose Kerr Hall Quad as their favourite space on campus, therefore making it the most popular. The second highest number of responses collected said that the pedestrian-only section of Gould Street was their favourite, with 13 members of the public choosing this space. The third most favoured 
public space surrounding Ryerson Campus was Devonian Pond, with 6 respondents choosing this space. The most unfavoured places, as per the survey, are Pitman Quad, Nelson Mandela Way and Bond Street with 1 respondents choosing each of these spaces.

Value of Public Space

After questioning the respondents about their favourite place, they were then asked the rationale behind why they appreciated that site. A list of nineteen rationales were listed and respondents were given the option to choose as many as they deemed fit for the space. The following section answers the questions of what were the perceptions of these most popular spaces.

The Kerr Hall Quad

The survey demonstrated that forty-four people chose the Kerr Hall Quad as their favourite space on campus. When the survey dove deeper to understand the perceptions of the Kerr Hall Quad, almost every value available to choose was selected to express why the respondents identified this place as their preferred location on campus. This shows that this space provides value to the public in many different ways. From the respondents that chose the Kerr Hall Quad as their favourite space, the most frequently cited rationales for choosing this space were because "It is a leafy green oasis", "It is restful and provides relaxation", "You can be at peace there" and "You can sit or lie and sunbathe". 
Gould Street

The second most popular space identified on campus was Gould Street. The responses as to why respondents chose this space as their preferred place are different than those identified for the Kerr Hall Quad. From the responses, those who chose Gould Street said they liked it best because, "You could see people there", "It is close to where I study", and "There is a cafe or food there".

Devonian Pond

According to those respondents that favoured Devonian Pond, their rationale behind choosing this space is due to the opportunity to people watch, go skating as well as because it is a place where socialization can occur.

Overall Results

It is valuable to understand why those that completed the survey enjoy various public spaces. When amalgamating all the data to understand the overall rationales in regard to why respondents appreciate the spaces on campus, the most frequent responses were because it is a good place to see people, it provides rest and relaxation, you can meet your friends there and it is a place that you can catch some sun. From this, we can infer that public spaces on campus provide a social environment for relaxation and passive viewing of life moving by.

Duration of Stay

Respondents to the survey also discussed the duration of stay within their preferred public space on campus during the warmer and colder months. 
The Kerr Hall Quad.

It is interesting to note that during the winter and fall, the majority of respondents, $79 \%$, said they just walk through the Kerr Hall Quad, but during the spring and summer those that "just walk through" reduces for $30 \%$. However, during the summer months, $61 \%$ say that they stay in the Kerr Hall Quad for a while.

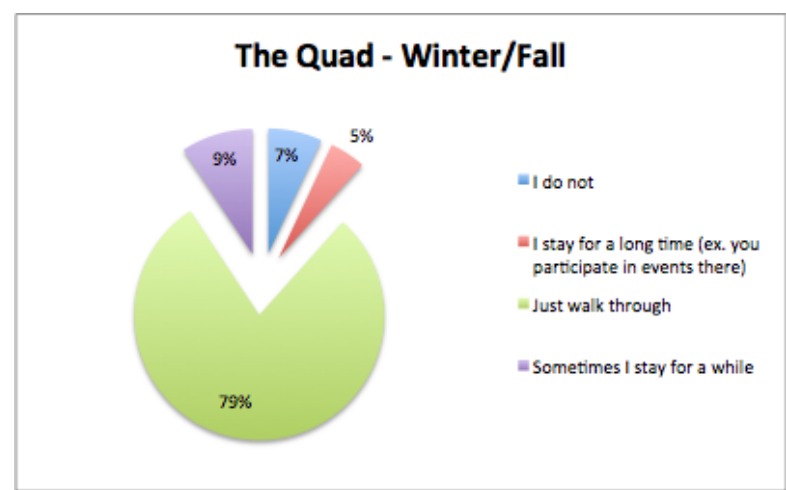

Figure 5: The Quad Duration of Stay in Winter and Fall

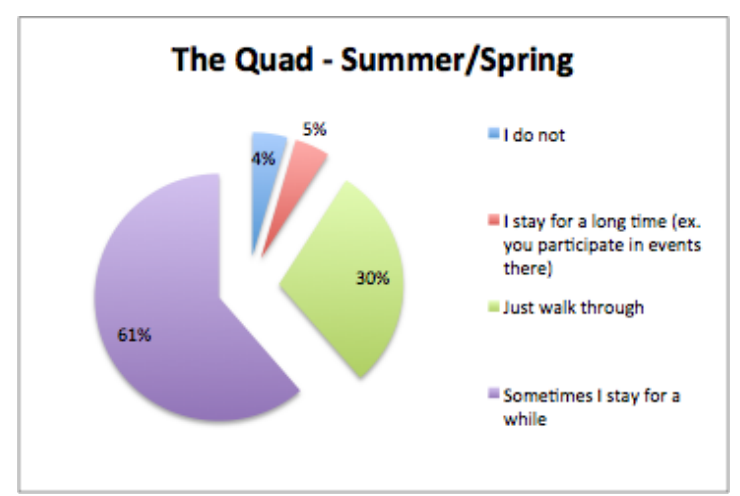

Figure 6: The Quad Duration of Stay in Summer and Spring

\section{Gould Street}

A large portion of Gould Street on campus, west of Church, is closed off to vehicular traffic and is designated for pedestrians only. It is a spot that acts as the main connection point for those moving around campus and a marketplace during the summer months. In the winter and fall seasons, $62 \%$ of respondents said that they don't spend much time there and just use it to walk through, however, the remainder of respondents conveyed that they sometimes stay there for a while. In the summer amd spring months, $54 \%$ of people surveyed said they stay there for a while, and $38 \%$ use it to just walk through. Some respondents mentioned that they do not use Gould Street during the summer, this might be attributed to the fact that they do not attend school during that time. 


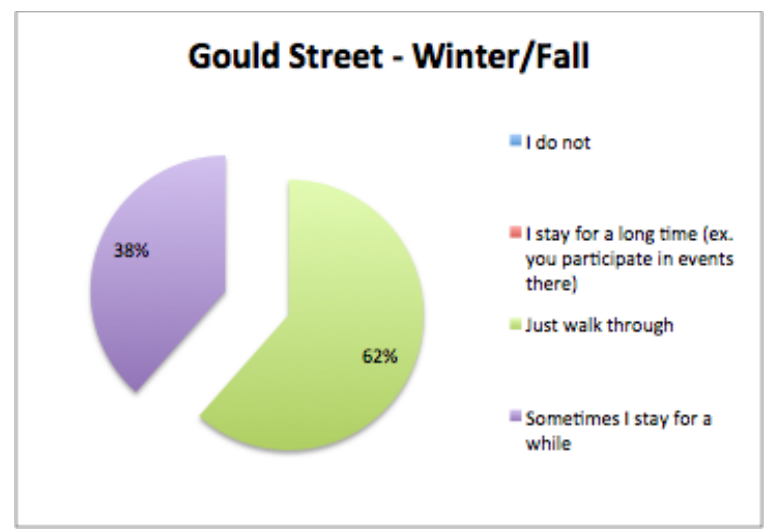

Figure 7: Gould Street Duration of Stay in Winter and Fall

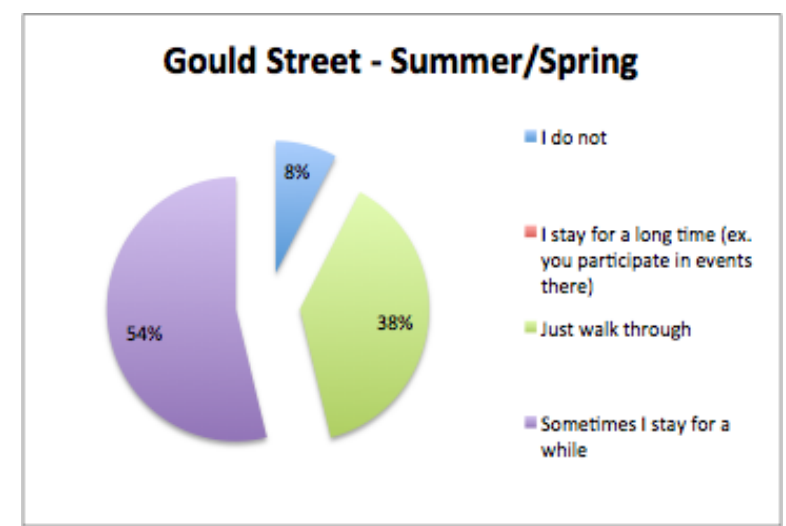

Figure 8: Gould Street Duration of Stay in Summer and Spring

\section{Devonian Pond}

Devonian Pond is an open space in the summer and a skating rink during the cold winter months. This is the public space with the highest percentage of respondents remarking that they stay for a long time during the winter and fall (11\%), which may be attributed to the winter specific activity. Conversely, no one responded that they stay in the space for a long time during the summer and spring months. There was an even split during the winter and fall months as $44 \%$ say they stay for a while, and $45 \%$ responded that they just walk through. Alternately, during the summer and spring, 22\% of people said that they do not go to the pond during these months, which may be attributed to the fact that many students are not on campus during these times or that there is not much to do in the space during the summer. Also, a smaller percentage of respondents reported that they stay for a while in the space, as only $32 \%$ said they do and $45 \%$ reported they just walk through. 


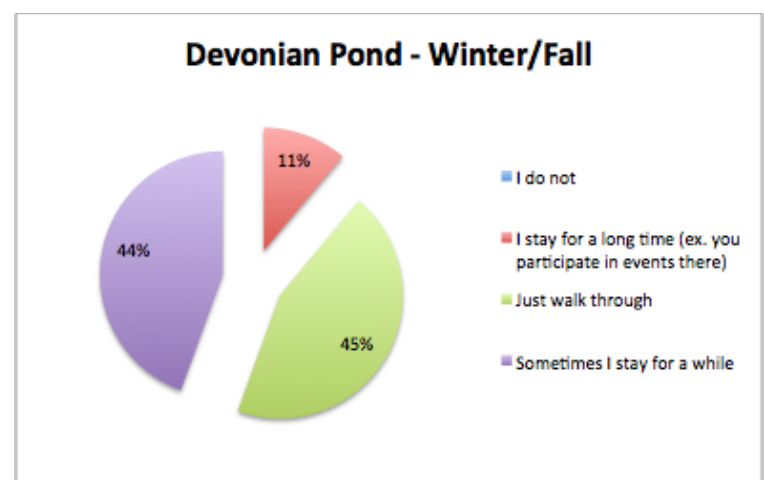

Figure 9: Devonian Pond Duration of Stay in Winter and Fall

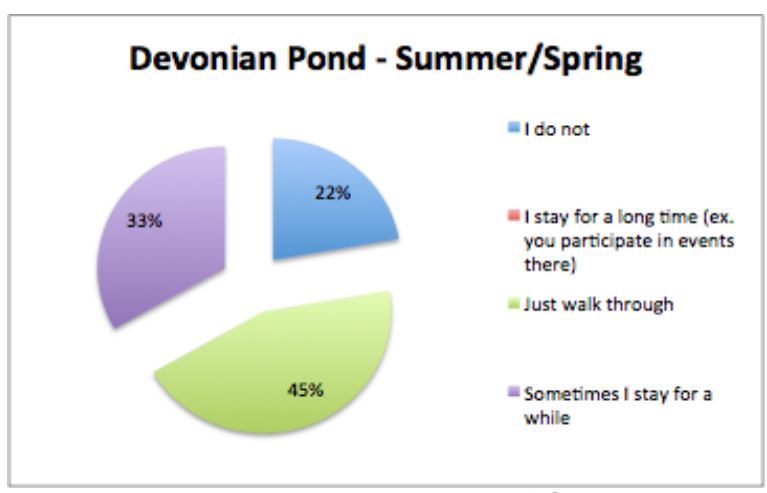

Figure 10: Devonian Pond Duration of Stay in Summer and Spring

Overall Duration

The data from the responses regarding the length of stay within public spaces were amalgamated in order to see the more general behaviour of those within public spaces during the winter and fall as well as the summer and spring. Overall, during the winter and fall months, the majority of respondents utilize their preferred public space passively and claim to "just walk through". However, during the summer and spring time this changes, and about the same percentage of respondents who "just walked through" during the winter and fall tend to stay in the public space for a longer period of time.

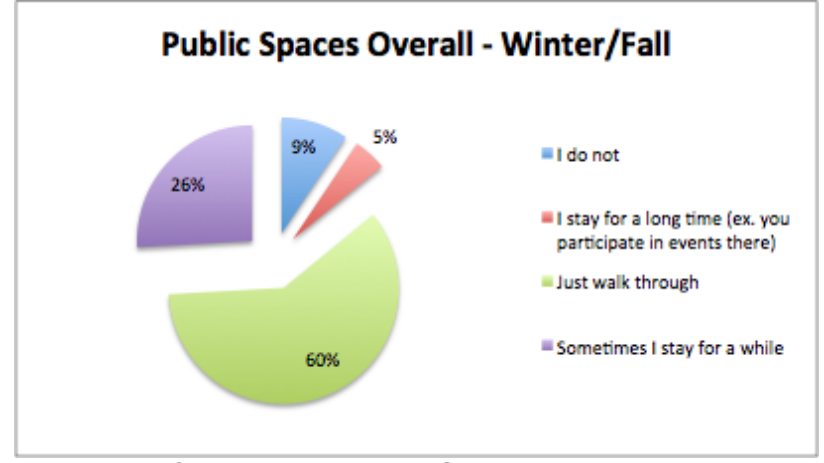

Figure 11: Overall Duration of Stay in Winter and Fall

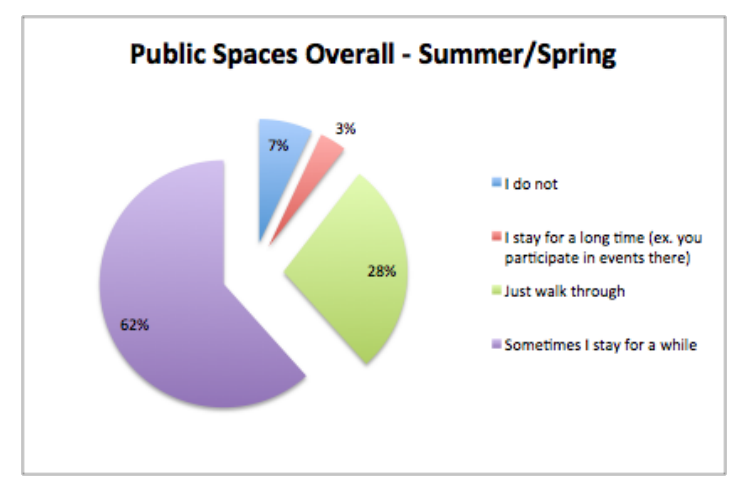

Figure 12: Overall Duration of Stay in Summer and Spring. 
Frequency of Use

As important as it is to understand how long a person staying in a public space, the amount of times they visit this space is important when discussing the value of a space. In the following, the three most favoured public spaces, as per the survey respondents, were explored in relation to the frequency in which users visit the space in both the colder and warmer months of the year.

The Kerr Hall Quad

By far the most favoured space identified on Ryerson Campus was the Kerr Hall Quad, but how often does the public visit this space? During the winter and fall, it has been found that $43 \%$ of respondents visit this space once in a while, however, $27 \%$ replied that they interact with the space a couple times a week. In the warmer months, during the summer and spring those two responses were also the most popular, however, $39 \%$ say they visit the space a couple times a week whereas $34 \%$ visit it once in awhile.

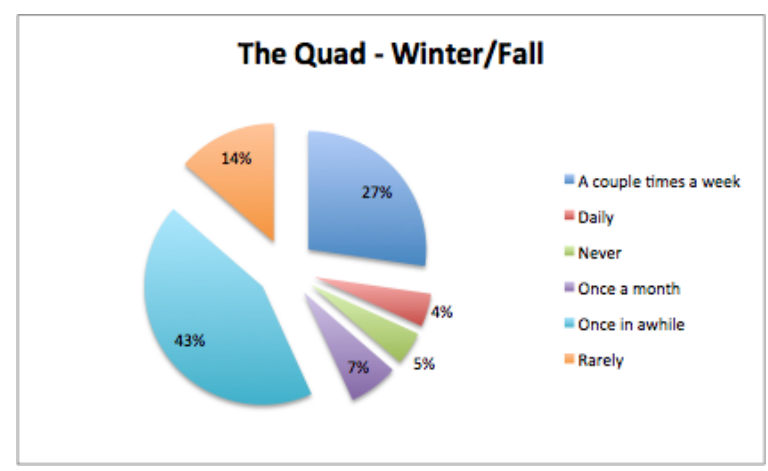

Figure 13: Frequency of Use in Winter and Fall

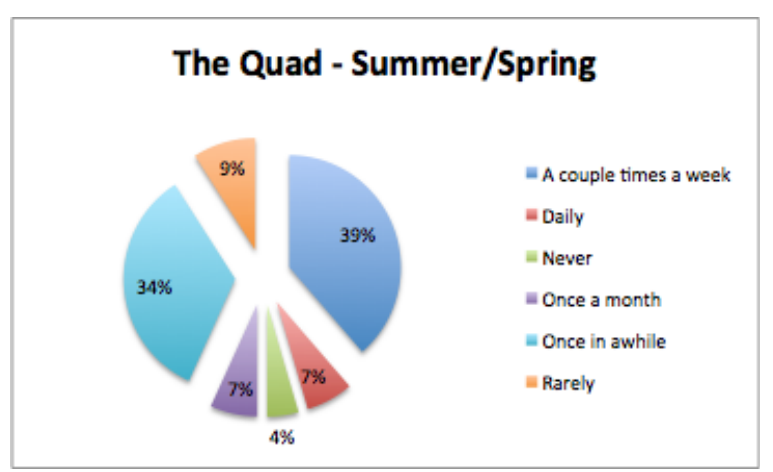

Figure 14: Frequency of Use in Summer and Spring 


\section{Gould Street}

When referring to Gould Street, this is a public space that has been reported to be utilized daily by $69 \%$ of respondents, or a couple times a week by $23 \%$. The central location and the fact that it is a pedestrian pathway may be the rationale behind this being a frequently visited public space. During the summer and spring months, there is a split between respondents that utilize the space daily (38\%) and those that rarely visit it (38\%).

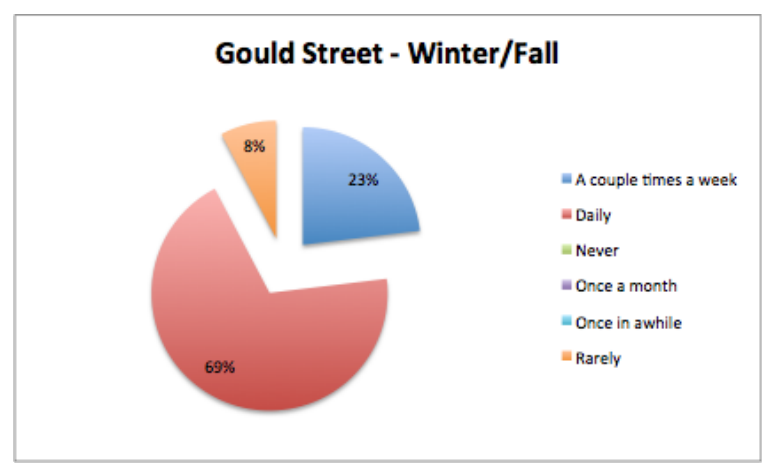

Figure 15: Frequency of Use in Winter and Fall

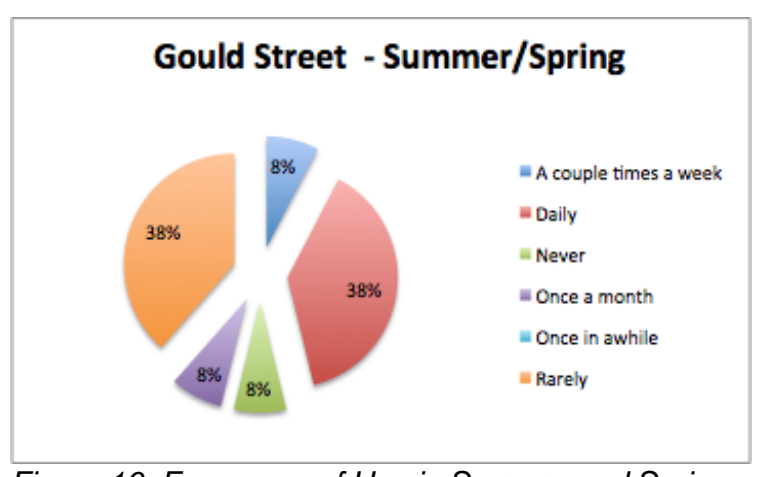

Figure 16: Frequency of Use in Summer and Spring

Devonian Pond

When assessing the frequency of use of Devonian Pond, 67\%, suggest they access this space a couple of times a week during the winter and fall, however, during the summer and spring that number reduces to $22 \%$. During the summer and spring, $45 \%$ of respondents reported that they rarely visit this space, which does not come as a surprise considering the programming for this space occurs mostly during the winter. 


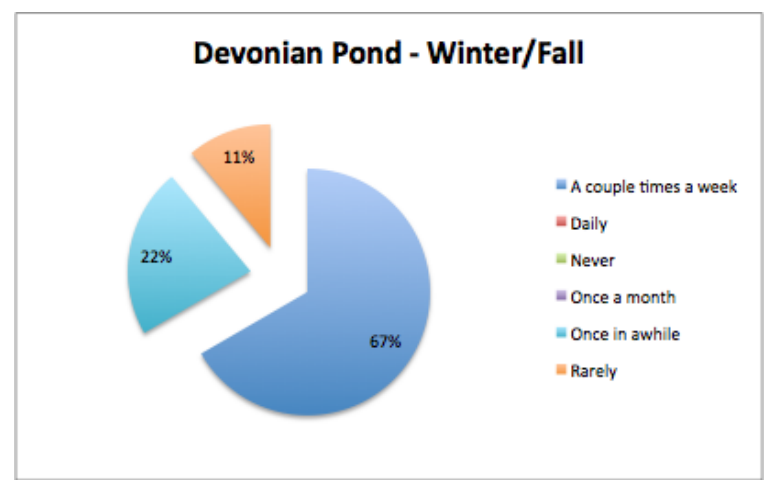

Figure 17: Devonian Pond Frequency of Use in Winter and Fall

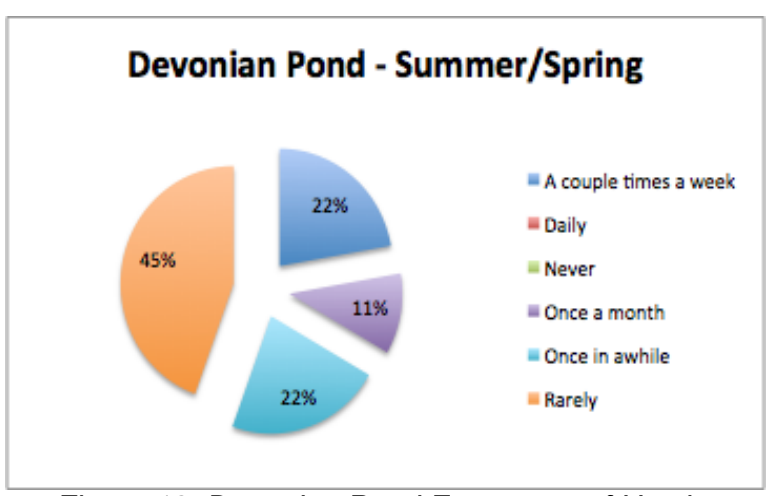

Figure 18: Devonian Pond Frequency of Use in Summer and Spring

Overall Frequency

When looking at the overall frequency of use in public spaces at Ryerson, there is not a big trend that differentiates the various seasons as one would expect.

Something of interest that emerges is that during the summer and spring there is a higher percentage of respondents that reported that they rarely use the public spaces, which as mentioned earlier, is perhaps due to the fact that they do not attend school during these months. However, that might suggest that Ryerson should think about incorporating more activation of its public spaces during the winter and fall.

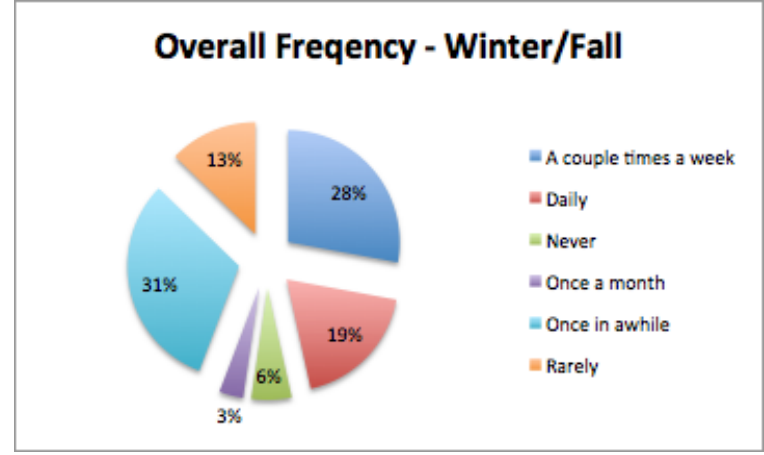

Figure 19: Frequency of Use in Winter and Fall

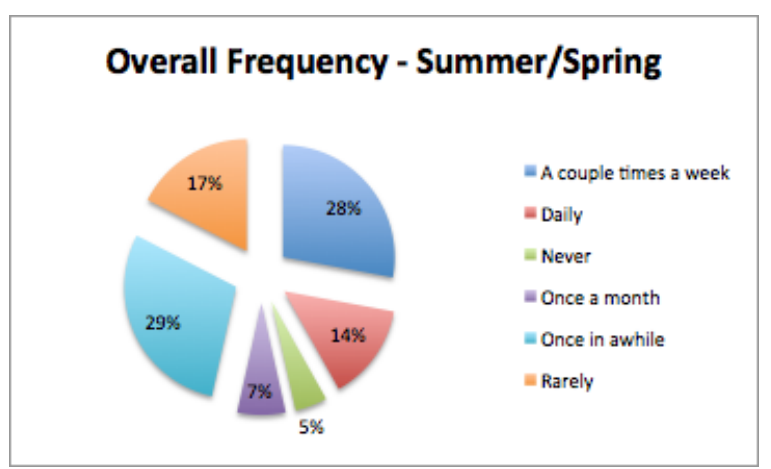

Figure 20: Frequency of Use in Summer and Spring 
Attraction to Space

Overall, it was found that the majority of survey respondents enjoy their chosen public space due to the fact that it is located in a central spot on Ryerson Campus. Respondents were also questioned in regard to the quantity of public spaces that are present on campus. Out of the responses, the majority of respondents felt that there were very few parks at Ryerson. It should be noted that not one person stated that there were too many parks on campus which may be an indication that this amount either does not exist or that there could be more parks on campus.

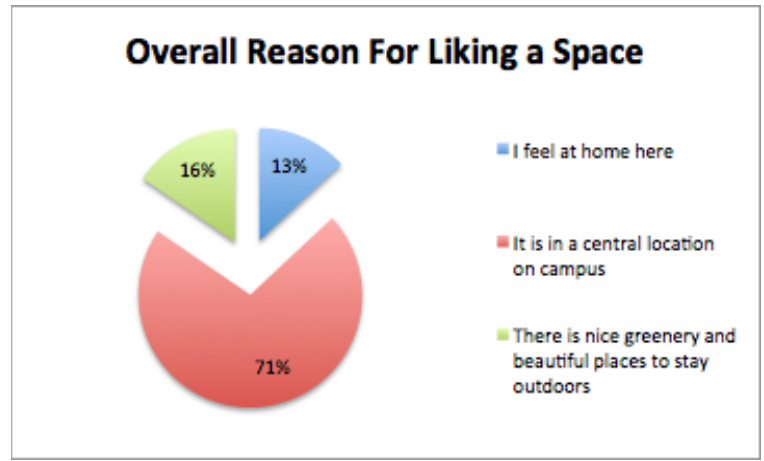

Figure 21: Overall Reason For Liking a Space

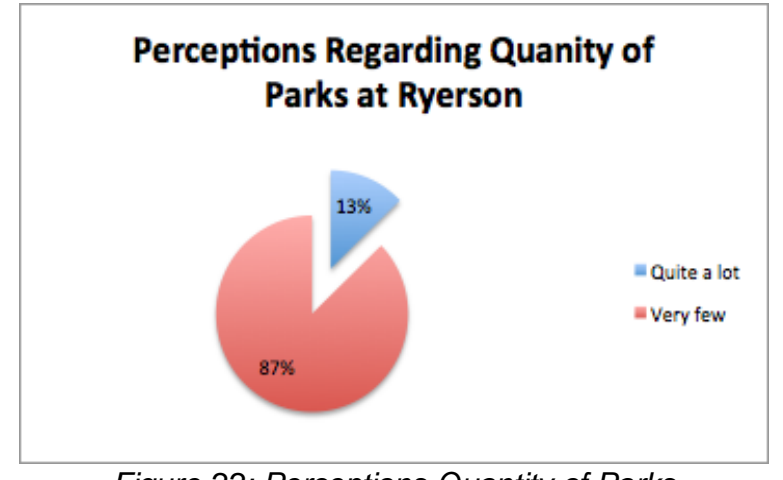

Figure 22: Perceptions Quantity of Parks 
The Sociotope Map

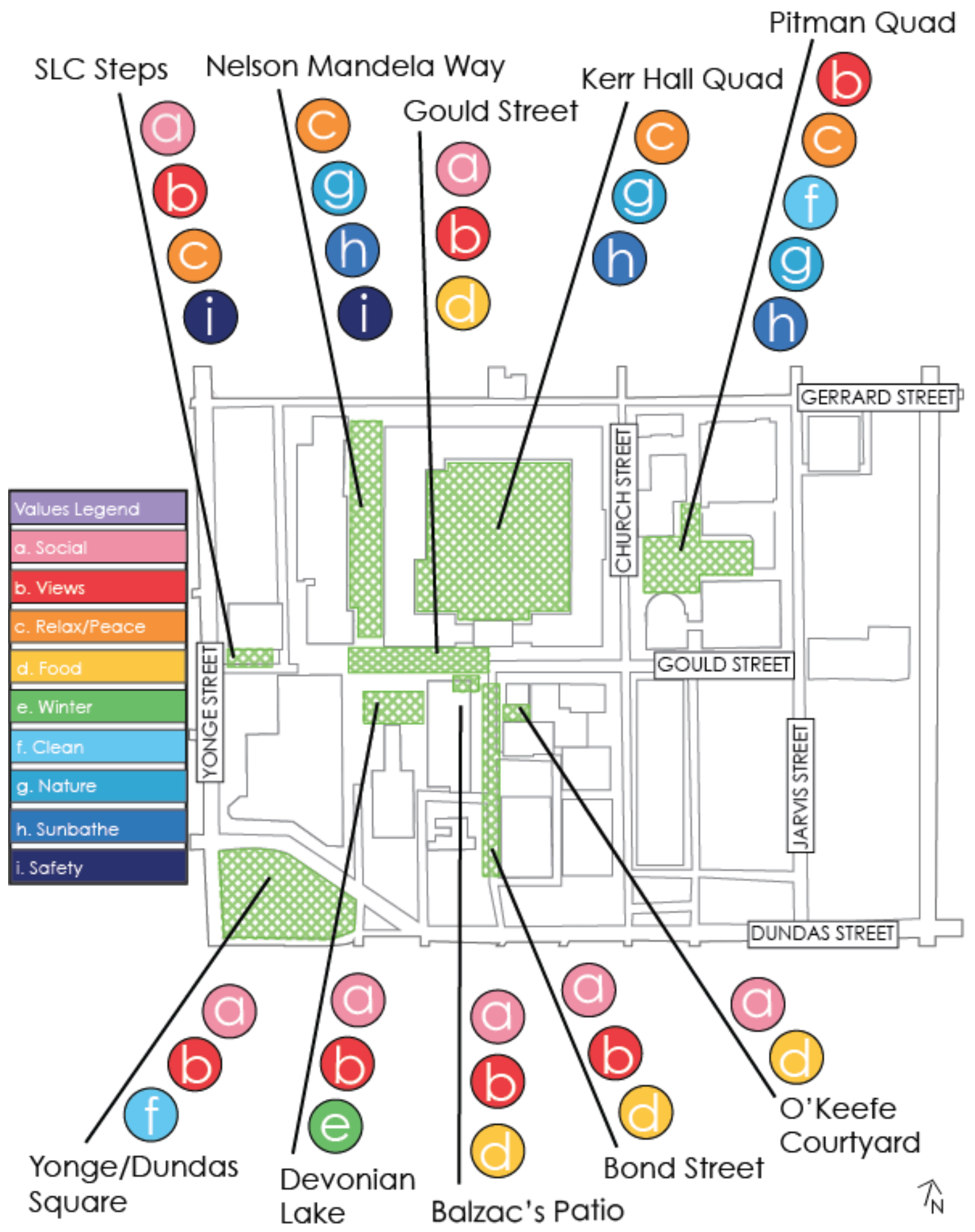

Figure 23: The Sociotope Map of Public Space In and Around Ryerson University Campus 
The sociotope map demonstrates some patterns regarding perceptions of space on Ryerson Campus. The public spaces valued for social on campus are mostly situated on the south-west side of Ryerson campus. Many of the respondents commented that they enjoy their chosen public space due to the views the space provides, whether that may be the view of other people or general views. The spaces on the northern side of Gould Street have been identified as being spaces where relaxation occurs and where respondents find peace. It is interesting to see that these spaces are further away from Dundas Street, which is often busy with vehicular traffic. Few respondents to the survey perceived public spaces on Ryerson to be of value during the winter months, however, this was not the case for Devonian Lake. When discussing the value of a clean space, this was more frequently noted for Pitman Quad and Yonge Dundas Square. Yonge Dundas Square, although not a part of Ryerson Campus, is seen as an extension of it, as per the respondents and is privately owned and maintained.

Ryerson Campus is situated in an urban location surrounded by buildings, however, the value of nature was noted within Nelson Mandela Way, Kerr Hall Quad, and Pitman Quad. This is interesting as these spaces may not be aligned with the traditional perception of nature, however, they offer this value to the respondents. The value of sunbathing was noted at Nelson Mandela Way, Kerr Hall Quad and Pitman Quad. When discussing safety, there are only two spaces on campus that made their way into the sociotope map which are the SLC Steps and Nelson Mandela way. Unfortunately, no follow-up questions were asked to understand why these spaces are 
valued for their safety by respondents and why other spaces are not perceived as safe on campus by a majority of their users. 


\section{Discussion}

Sociotope Application

The Ryerson Campus is one with public spaces that play important roles for its users in a variety of ways. The Kerr Hall Quadrangle is one of the largest public spaces on campus and by far the most cited favourite public space. This nestled away square carved into Ryerson Campus is sheltered from cars and fast-moving traffic, relating to literature regarding safety perceptions (McCormack et al., 2010). The public spaces have been found to possess nine categories of values which are: social, views (people and things), relax \& peace, food, winter activity, clean, nature, sunbathe and safety. These values are similar to the values outlined in the relevant literature. However, when comparing with the direct use values utilized in the Swedish example, the list is much shorter (Ståhle, n.d.). This can be attributed to the number of activities possible on the limited green space at Ryerson University.

Seasonal variations influence duration of stay within the identified public spaces. During the spring and summer seasons, respondents have been found to be more likely to stay in their preferred public space for a while. However, during the winter and fall, there is a higher chance that they will use their favoured spaces passively and solely walk through them. This finding is most likely related to the lack of public spaces on campus that provide activities for winter and cold weather. McCormick et al (2010) discuss that programming a space provides an opportunity for socialization, which relates to Devonian Lake and its increased use during the winter. Cold weather may discourage users from staying outside for longer periods, there providing an activity may encourage public space use. 
When assessing the frequency of use from the temporal standpoint, a divergent finding emerges. From the picture that the duration of stay portion uncovers, there does not seem to be a large difference in the overall frequency of use of the spaces in the winter and fall as well as the summer and spring seasons. Perceptions of space literature have not been shown to allude to climate changes and the influence of perceptions or values due to the changes in weather. This is an area that should be further explored in future investigations. The findings may be attributed to the fact that many of people that were forwarded the survey were students and the majority of classes at Ryerson University run from September to April, therefore, many of these students may not present during the summer.

Within the survey, respondents were asked to comment on their use and duration of stay in winter and fall as a whole and spring and summer as a whole. However, this is nuanced, due to the fact that there are times within the fall and spring, in Toronto, when there is weather that is as warm as a summer day or as cold as a winter day respectively. As respondents were asked during the winter to comment on their use and frequency of stay in these grouped seasons, their responses may have differed if they were asked during another season.

To create a more holistic understanding of users' experiences it is recommended that this survey is completed during different seasons. Since the survey was only available online, it omitted feedback from users of the space that do not have access to technology. If the study were to be repeated, it is recommended that a larger audience is reached as well as to capture responses from those utilizing the public spaces. 
Overall, the sociotope is concerned with users' positive experiences in public spaces but does not directly address undesirable public spaces and potential interventions to improve these spaces. For the future application of this tool at the municipal level it should also attempt to better understand what makes respondents uncomfortable in the space as other researchers have done in the past (Jurkovic, 2014). This may answer questions about safety within a space, which has been explored deeper at other institutions (Blöbaum \& Hunecke, 2005). It is possible that using the data from what users like, researchers may make an assumption that directing similar uses within these spaces may increase desirability although, it may be a large assumption to make.

Furthermore, within the survey, respondents were given the option to leave a question blank and proceed to the follow-up questions. Due to this option, some respondents failed to provide their favourite space, leaving the remaining information useless. In the future, it is recommended that the boundaries of the study area are defined so the respondents would have solely commented on these spaces within them. A useful tool within this phase would have been a map of Ryerson Campus to give respondents an idea of the appropriate locations to comment on that fall within the scope of the research.

Tool Utility

The sociotope is a creative method which illustrates perceptions and values through the use of traditional mapping. Solely by virtue of creating this map, it demonstrates the consideration and value that this current paradigm shift in planning 
has put into public engagement and the interest of the public. Utilizing a variety of questionnaires and focus groups, it attempts to find the root of what makes various public spaces important to those that interact with them. This leads to an understanding, by the planning department, of what those values are and provides them with information about what uses are to be relocated if development occurs. Additionally, it can have the impact of identifying what aspects might be missing in the urban fabric. Finally, it opens up a dialogue process about sentiments that exist in space that the rational planning lens ignores. Within planning processes, in the context of Ontario, public consultation is often completed due to the duty to consult, however, it is not seen as being meaningful or largely altering the outcomes of plans. Through the use of the sociotope method, citizens are involved early in the process, therefore, their voices are considered before development even is thought to occur. This may have a positive outcome regarding relationships between the public and government.

When speaking of the assessment tools that the three, aforementioned municipalities employ to create parkland policies, it is evident that a great deal of work and thought goes into public engagement, quantitative and qualitative research. As multiple stakeholders are engaged throughout the process, it is not clear how different user groups value or perceive space as their responses are said to be integrated or providing information to produce the report but not explicitly displayed.

In the Edmonton example, they utilized an online mapping tool to engage citizens. Respondents were able to place a pin down at a geographic location on a map and write a comment about that space. This may be a method that has the 
potential to complement the sociotope map, as it does relate to use of public spaces. They use the values of Celebration, Ecology and Wellness within their maps, however, these are very broad umbrellas that generally group a variety of uses and values (City of Edmonton, 2017).

In the City of Toronto's new Parkland Strategy, an online survey was also employed to obtain data from residents. The information which was collected through this process identified needs as well as gaps in provision, however, did not evaluate the public spaces that currently exist (City of Toronto, 2017b). This lost opportunity to employ the short questionnaire the sociotope tool utilizes could have provided City staff with information regarding park use and the social lens on these public spaces.

Commenting on the method of the sociotope as a whole, although it is a method that is meant to be very bottom up there is an inherent power conflict that occurs during the results synthesizing phase. The method takes into account an expert analysis of public spaces and their values as well as the evaluation of spaces by residents. From this information, the responses from both groups are synthesized to create the sociotope map. Through this process of synthesizing the material, there are evidently power structures at play as it raises questions regarding what assessment is valued higher and is ultimately expressed in the sociotope map. Relating to the aforementioned literature emerging from London, evaluations and values of space are divergent in the eyes of professionals in urban-related fields when compared to users of space (Pugalis, 2009). There are times when the expert may perceive certain materials or architectural details which are not noticed by the public, and these may blur their understanding and evaluation of space. This may be 
avoided by having safeguards put in place to ensure that the evaluations by the experts are not overruling those from the public.

Although the sociotope is a useful method to gain an understanding of humans perceptions of public space there are limitations to utilizing this method, which was found through this investigation. First off, there is limited information outlining how to complete the expert analysis as it is only available in Swedish. The information which was available outlined that the expert was to assess the various spaces two times a year to account for seasonal variations of use. For a research project with no funding as well as a limited time to be completed, this would be difficult to attain. It is recommended that this material is outlined in a handbook type format and is available in various languages so it can be employed in different places around the world.

This tool is useful as it provides an understanding of the values within public spaces and as one that builds relationships between the public and municipalities. Although there are caveats within the method that could be improved upon, these could be altered to obtain and display meaningful information. It is recommended that this tool is employed within municipalities that expect to see growth pressures infringe on valuable public space. 


\section{Conclusion}

As a result of this study, it is evident that sociotope mapping is a relevant and useful tool that has the potential to engage residents early in the planning process and seeks to comprehend the values intrinsically embedded in the urban landscape. This is an inclusive tool, however, it is wildly inaccessible as its process is only available in Swedish. The only means for it to reach its true utility is if it is made accessible to professionals engaging in parks planning. Through the implementation of this tool, planners may engage the public before development is imminent, understand the public's perceptions and values of space, therefore creating more useful and meaningful public space. Through it application at Ryerson University's campus, it is evident that it displays what users believe are the greatest utility, however, to fully understand perceptions of space, a less biased process and a more in depth survey is required. 


\section{Appendix A}

Survey

What is your age?

What is your current gender identity? (Check all that apply)

$$
\text { Female }
$$
Male

Trans male/Trans man Trans female/Trans woman Genderqueer/Gender non-conforming Different identity (please state):

1. Name your favorite outdoor space at Ryerson University - choose only one (favorite place or park name, add street name when it is located if needed)

2. Why do you like this place? Tick in one or more boxes

a. It is a leafy green oasis

b. It is restful and provides relaxation

c. There is life and movement

d. It is close to where I study

e. It is close to where I live

f. There is a cafe or other food

g. There are good seats

h. There are beautiful flowers and trees

i. You can meet your friends there

j. There is a sense of wild unspoiled nature

k. You can see wildlife

I. You can be at peace there

m. It's a safe place

n. You can play sports there

o. In the winter you can go skating

p. It's a good place to bring your dog

q. You see people there

r. It's nice and clean

s. There is beautiful artwork

t. You can walk or exercise

u. You can sit or lie and sunbathe

v. There is a nice view

w. Other

3. How often do you visit this place? tick for the different seasons

a. During the summer/spring season.

i. Daily.

ii. a couple of times a week. 
iii. once in awhile

iv. once a month

v. very rarely

b. During the winter/fall season.

i. Daily.

ii. a couple of times a week.

iii. once in awhile

iv. once a month.

v. very rarely

4. How long will you spend there? tick for the different seasons

a. During the winter/fall season

i. Just walk through

ii. Sometimes I stay for a while

iii. I stay for a long time, for example you participate at events there

b. During the summer/spring season

i. Just walk through

ii. Sometimes I stay for a while

iii. I stay for a long time, for example you participate at events there

5. How long does it take for you to get there from where you study?

a. At most five minutes

b. Between five minutes and ten minutes

c. more than ten minutes

6. How do you usually get there?

a. By foot

b. By bike

c. By car

d. By bus

e. By subway

7. What can be done to make the place even better?

a. No improvements are needed

b. Cleaning and maintenance needs improvement

c. The bushes must be trimmed

d. The lighting needs to be better

e. It needs more flowers and discounts.

f. It would be nice with $\mathrm{a} /$ more water features

g. More benches are needed

h. It would be good with a cafe or a small food kiosk

i. Security needs to be improved

j. Better crossings or footpaths would make it easier to get to the place

k. Noise protection is required to reduce traffic noise

8. Do you think there are very few, just too many or too many parks and green areas at Ryerson?

a. very few

b. quite a lot

c. far too many

9. What's nice at Ryerson's public spaces? tick in one or more boxes 
a. I feel at home here.

b. It is in a central location in town.

c. There is nice greenery and beautiful places to stay outdoors.

d. Other 


\section{Bibliography}

Allen, J., Amano, R., Byrne, D. P., \& Gregory, A. W. (2009). Canadian city housing prices and urban market segmentation. Canadian Journal of Economics/Revue canadienne d'économique, 42(3), 1132-1149.

Arnberger, A., \& Eder, R. (2012). The influence of green space on community attachment of urban and suburban residents. Urban Forestry \& Urban Greening, 11(1), 41-49. 10.1016/j.ufug.2011.11.003

Blöbaum, A., \& Hunecke, M. (2005). Perceived danger in urban public space: The impacts of physical features and personal factors. Environment and Behavior, 37(4), 465-486. 10.1177/0013916504269643

Bolund, P., \& Hunhammar, S. (1999). Ecosystem services in urban areas. Ecological Economics, 29(2), 293-301. doi:10.1016/S0921-8009(99)00013-0

Caves, R. W. (Ed.). (2005). Encyclopedia of the City. Taylor \& Francis.

City of Toronto. (2017a, October). Preliminary Neighbourhood Census Profile: 75. Church-Yonge Corridor. Retrieved from https://www.toronto.ca/ext/sdfa/Neighbourhood Profiles/pdf/2016/pdf1/cpa75.pdf

City of Toronto. (2017b, November). Parkland Strategy: Growing Toronto Parkland (Rep.). Retrieved from https://www.toronto.ca/wp-content/uploads/2017/12/95a5-pfrparkland-strategy-phase-1-report.pdf

City of Toronto. Parks Plan 2013-2017. Parks, Forestry and Recreation, Toronto, 2013.

Cooke, L. (2015). Are planning methods culturally neutral? Examining how planners read multicultural landscapes. Ryerson University, Toronto

COST (2012a) Case study - The Green Poster of Fredrikstad as a Tool for the Municipality Plan, http://www.cardiff.ac.uk/archi/research/cost8/case/greenblue/stockholmgreen.html. Accessed February 13, 2018.

West Vancouver (District of ). (2012). District of West Vancouver Parks Master Plan (Canada, Parks \& Rec). West Vancouver.

Fitzpatrick, M. (2016). Bridging theories, William H. Whyte and the sorcery of cities.Architecture and Culture, 4(3), 381-393. 10.1080/20507828.2016.1251214 (https://journals-scholarsportal- 
info.ezproxy.lib.ryerson.ca/details/20507828/v04i0003/381_btwhwatsoc.xml\#FN000 1)

Gehl, J. (2010). Cities for people Island Press.

Gehl, J., \& Svarre, B. (2013). How to study public life Island Press/Center for Resource Economics.

Gehl Institute. (2016, January 31). The Public Life Diversity Toolkit 2.0. Retrieved March 03, 2018, from https://issuu.com/gehlinstitute/docs/20160128_toolkit_2.0

Jacobs, J. (2016). The death and life of great American cities. Vintage.

Jurkovič, N. B. (2014). Perception, experience and the use of public urban spaces by residents of urban neighbourhoods. Urbani Izziv, 25(1), 107-125. 10.5379/urbaniizziv-en-2014-25-01-003

Kettunen, M., Vihervaara, P., Kinnunen, S., D’Amato, D., Badura, T., Argimon, M., \& Ten Brink, P. (2012). Socio-economic importance of ecosystem services in the Nordic Countries. Nordic Council of Ministers.

Lee, Y., Gu, N., \& An, S. (2017;2016;). Residents' perception and use of green space: Results from a mixed method study in a deprived neighbourhood in Korea. Indoor and Built Environment, 26(6), 855-871. 10.1177/1420326X16661024

Lo, A. Y. H., \& Jim, C. Y. (2010). Differential community effects on perception and use of urban greenspaces. Cities, 27(6), 430-442. 10.1016/j.cities.2010.07.001

Lorinc, J. (2015, April 21). PARKS IN CRISIS Part 1: All built up and no place to go. Retrieved March 24, 2017, from http://spacing.ca/toronto/2015/04/13/parks-in-crisispart-1-all-built-up-and-no-place-to-go/

Lynch, K. (1960). The image of the city MIT Press.

McCormack, G. R., Rock, M., Toohey, A. M., \& Hignell, D. (2010). Characteristics of urban parks associated with park use and physical activity: A review of qualitative research. Health and Place, 16(4), 712-726. 10.1016/j.healthplace.2010.03.003

Nasution, A. D., \& Zahrah, W. (2014). Community perception on public open space and quality of life in Medan, Indonesia. Procedia - Social and Behavioral Sciences, 153, 585-594. 10.1016/j.sbspro.2014.10.091

Németh, J. (2012). Controlling the commons: How public is public space? Urban Affairs Review, 48(6), 811-835. 10.1177/1078087412446445

City of Edmonton. (2017). Breathe: Edmonton's Green Network Strategy, Strategic Plan (Canada, City of Edmonton). Prepared by O2. 
Perovic, S., \& Folic, N. K. (2012). Visual perception of public open spaces in niksic. Procedia - Social and Behavioral Sciences, 68, 921-933. 10.1016/j.sbspro.2012.12.277

Project for Public Spaces. (2010, January 3). Placemaking Heros: William H. Whyte. Retrieved February 28, 2018, from https://www.pps.org/article/wwhyte

Pugalis, L. (2009). The culture and economics of urban public space design: Public and professional perceptions. Urban Design International, 14(4), 215-230. 10.1057/udi.2009.23

Risom, J., \& Gehl People. (2016, April 19). Downtown Toronto Growing Up. Retrieved March 01, 2018, from http://gehlpeople.com/blog/downton-toronto-growing-up/

Sloan, W. (2016, December 08). On patrol with campus security: We took a tour of Ryerson with the Security and Emergency Services team. Ryerson Today. Retrieved from https://www.ryerson.ca/news-events/news/2016/12/on-patrol-with-campussecurityl

Ståhle, A. (2013). Sociotope mapping-exploring public open space and its multiple use values in urban and landscape planning practice. $N A, 19(4)$.

Ståhle, A., Sandberg, A., \& Nordström, M. (2003). Sociotophandboken: Planering av det offentliga uterummet med Stockholmarna och sociotopkartan. Stockholm: Rapport SBK, 2.

Ståhle, A. (n.d.). The sociotopes and landscape of inhabitants. Institut D'Amenagement et D'Urbanisme. Retrieved March 3, 2018, from https://www.iauidf.fr/fileadmin/NewEtudes/Etude_945/The_sociotopes_and_landscape_of_inhabitan ts.pdf

Stockholm Stad. (2017, October 2). Green Structure Planning. Lecture presented by Ulrika Egerö at City Planning Administration Presentation in Stockholm Stad, Stockholm.

Whyte, W. H., \& Project for Public Spaces. (2001). The social life of small urban spaces. Project for Public Spaces. 